\title{
Biological and Molecular Characterization of an Isolate of Tobacco streak virus Obtained from Soybeans in Brazil
}

\author{
Álvaro M. R. Almeida ${ }^{1}$, Junichi Sakai ${ }^{2}$, Kaoru Hanada ${ }^{2}$, Thalita G. Oliveira ${ }^{3}$, Priscila Belintani ${ }^{4}$, \\ Elliot W. Kitajima ${ }^{5}$, Eliezer R. Souto ${ }^{6}$, Tanara G. de Novaes ${ }^{7} \&$ Paulo S. Nora
}

${ }^{1}$ Embrapa Soja, Cx. Postal 231, CEP 86001-970, Londrina, PR, Brazil, e-mail: amra@ cnpso.embrapa.br; ${ }^{2}$ Laboratory of Molecular Plant Patholology, Kyushu National Agricultural Experimental Station, 2421 Suya, Kikuchi, Kumamoto, 8611192, Japan; ${ }^{3}$ UNOPAR, Av. Paris, 675, CEP 86041-140, Londrina, PR; ${ }^{4}$ IBILCE, UNESP, Rua Cristóvão Colombo 2265, S. J. Rio Preto; ${ }^{5}$ ESALQ, Setor de Fitopatologia, Cx. Postal 9, CEP 13418-900, Piracicaba, SP; ${ }^{6}$ Universidade Estadual de Maringá, CCA- DAG, Av. Colombo, 5790, CEP 87020-900, Maringá, PR; ${ }^{7}$ UNIFIL, Av. Juscelino Kubitschek 1626, CEP 86020-000, Londrina, PR; ${ }^{8}$ Universidade Estadual de Londrina, Rod. 369 Km, CEP 86000-970, Londrina, PR

(Aceito para publicação em 07/04/2005)

Corresponding author: Álvaro M. R. Almeida

ALMEIDA,A.M.R., SAKAI, J., HANADA, K., OLIVEIRA, T.G., BELINTANI, P., KITAJIMA, E.W., SOUTO, E.R., NOVAES, T.G. \& NORA, P.S. Biological and molecular characterization of an isolate of Tobacco streak virus obtained from soybeans in Brazil. Fitopatologia Brasileira 30:366-373. 2005.

\begin{abstract}
A virus was isolated from soybean (Glycine max) plants with symptoms of dwarfing and bud blight in Wenceslau Braz County, Paraná, Brazil. The host range and properties resembled those of Tobacco streak virus (TSV). The purified virus showed three peaks in a frozen sucrose gradient. Antiserum was produced and the virus was serologically related to TSV. Electron microscopy detected $28 \mathrm{~nm}$ spherical particles. Coat protein (CP) had a Mr of 29.880 Da. A fragment of 1028 nt was amplified, cloned and sequenced. One open reading frame with $717 \mathrm{nt}$ was identified and associated to the CP. The CP gene shared 83\% identity with the sequence of TSV CP from white clover (Trifolium repens) (GenBank CAA25133). This is the first report of the biological and molecular characterization of TSV isolated from soybeans. It is proposed that this isolate be considered a strain of TSV named TSV-BR.
\end{abstract}

Additional keywords: nucleotide sequence, Elisa, host range.

\section{RESUMO}

Caracterização biológica e molecular de um isolado de Tobacco streak virus obtido de soja no Brasil

Um vírus foi isolado de plantas de soja (Glycine max) cultivadas em Wenceslau Braz, Estado do Paraná, com sintomas de nanismo e queima do broto. O vírus foi caracterizado por meio de hospedeiros diferenciais e propriedades biológicas como sendo um isolado do Tobacco streak virus (TSV). O vírus purificado apresentou três picos em gradiente de sacarose congelado. Anti-soro produzido contra o vírus foi sorologicamente relacionado ao TSV. Microscopia eletrônica detectou partículas esféricas com $28 \mathrm{~nm}$ de diâmetro. A proteína do capsídio (PC) apresentou massa molecular de 29.880 Da. Um fragmento de 1028 nt foi amplificado, clonado e seqüenciado. Uma ORF com 717 nt foi identificada e associada com a PC, a qual compartilha $83 \%$ de identidade com a seqüência da PC do isolado de TSV de trevo branco (Trifolium repens) (GenBak CAA25133). Este é o primeiro relato da caracterização biológica e molecular de um isolado de TSV de soja. Propõe-se que o isolado seja considerado uma estirpe do TSV denominada TSV-BR.

Palavras-chave adicionais: seqüenciamento de nucleotídeos, Elisa, gama de hospedeiros.

\section{INTRODUCTION}

A recent outbreak of soybean [Glycine $\max (\mathrm{L}$. Merril] bud blight in Wenscelau Braz County, State of Paraná, Brazil, may be an indication of the occurrence of a virus disease. The outbreak occurred in an area close to a region where the presence of Tobacco streak virus (TSV), family Bromoviridae, genus Ilarvirus, is historical. Preliminary evaluations using electron microscopy of infected leaves showed the presence of spherical particles. Additional studies proved that TSV was responsible for the problem. Although no resistance to this virus has been found in the soybean germplasm the disease has been controlled by delaying the sowing date (Almeida \& Corso, 1991; Almeida et al., 1994).

The TSV was identified in tobacco (Nicotiana tabaccum L.) plants in Brazil in 1940 (Costa, 1945), and it is currently known to infect several cash crops such as cotton (Gossypium hirsutum L.), tomato (Lycopersicon esculentum Mill.), tobacco (Nicotiana tabacum L.), soybean, peanut (Arachis hypogaea L.), sunflower (Helianthus annuus L.) and some weeds (Costa \& Carvalho, 1961). The association of soybean bud blight and TSV was reported for the first time in 1955 (Costa et al., 1955). At that time, the authors mentioned that similar symptoms were described in soybean in the USA, but these symptoms were caused by Tobacco 
ringspot virus (TRSV), family Comoviridae, genus Nepovirus. The disease was called soybean bud blight by Costa et al. (1955). Since then, several other viruses inducing similar symptoms have been described on soybeans in Brazil (Costa, 1982), causing serious confusion in field diagnosis.

Disease symptoms caused by TSV started to appear 15-20 days after sowing, when plants exhibited browning buds which later curled downward. Yield losses of up to $100 \%$ have been reported in soybean fields in Brazil. Studies have shown that the disease is endemic in specific regions where high populations of the vectors Thrips tabacci Linderman and Frankliniella occidentalis Pergande (Kaiser et al., 1982) have developed due to the simultaneous presence of a weed (Ambrosia polystachia L.) that is a known host of the virus (Costa \& Carvalho, 1961). Another vector species (Microcephalothrips abdominalis Crawford) has also been reported by Greber et al., 1991. However, the transmission by thrips was firstly demonstrated by Costa \& Lima Neto (1976).

TSV has a tripartite single-stranded messenger-sense RNA genome. The RNAs 1 and 2 encode proteins involved in viral RNA replication, whereas RNA 3 encodes a protein required for cell-to-cell movement. The viral coat protein (CP) is expressed by a subgenomic RNA, designated RNA 4, collinear with the 3' end of RNA 3 (Bol, 1999). Studies on ilarviruses revealed that in addition to functioning as a structural protein, the $\mathrm{CP}$ is also involved in many steps of virus replication.

In this report we present the biological and molecular characteristics of a Brazilian isolate of TSV as well as a phylogenetic analysis of the CP gene as compared with other ilarviruses.

\section{MATERIALS AND METHODS}

\section{Virus isolate and host range}

A virus was isolated from soybean plants with typical symptoms of bud blight as well as from plants of $A$. polystachia with mosaic symptoms in Wenceslau Braz County. Infected leaves were ground in chilled $0.01 \mathrm{M}$ sodium phosphate buffer $\mathrm{pH} 7.0$ with $0.1 \%$ 2mercaptoethanol.

Mechanical inoculation was performed in leaves previously dusted with fine charcoal. Inoculated leaves were washed with running water and maintained in a greenhouse under temperatures ranging from $18^{\circ} \mathrm{C}$ to $35^{\circ} \mathrm{C}$, depending on the season. For the host range experiment plants were kept in sterilized soil with four plants per pot and two pots of each botanical species were inoculated. Plants were assayed two and four weeks after inoculation by symptomatology and indirect ELISA (Koennig, 1981).

\section{Virus purification, nucleoprotein analysis and western blotting}

Infected leaves from tobacco cv. Sansun 'NN' were ground in $0.01 \mathrm{M}$ potassium phosphate buffer, $\mathrm{pH}$ 8.0 (2:1 w/v) containing 1\% 2-mercaptoethanol. The slurry was filtered in a double cheesecloth, clarified with chloroform $(1 / 2 \mathrm{vol})$ and stirred for $20 \mathrm{~min}$ at $4{ }^{\circ} \mathrm{C}$. The extract was centrifuged at $10,000 \mathrm{~g}$ for $10 \mathrm{~min}$ at $4{ }^{\circ} \mathrm{C}$ and the supernatant was mixed with $6 \%$ PEG 8,000 at $4{ }^{\circ} \mathrm{C}$ for $2 \mathrm{~h}$. After low speed centrifugation $(10,000 \mathrm{~g}$ for $10 \mathrm{~min})$ the pellet was dissolved overnight at $4{ }^{\circ} \mathrm{C}$. After another low speed centrifugation the supernatant was centrifuged at $180,000 \mathrm{~g}$ for $2 \mathrm{~h}$ in a swinging bucket rotor using $25 \%$ sucrose frozen gradient (Baxter-Gabbard, 1972; Davis \& Pearson, 1978). The virus was fractionated using an ISCO density gradient fractionator and UV analyzer. Fractions were diluted in 0.01 $\mathrm{M}$ potassium phosphate buffer, $\mathrm{pH} 8.0$ and centrifuged at $100,000 \mathrm{~g}$ for $90 \mathrm{~min}$. The pellet was dissolved and centrifuged at $10,000 \mathrm{~g}$ for $10 \mathrm{~min}$ and the supernatant rescued and stored. Virus yield was determined by assuming an extinction coefficient of 5.1 (Salazar et al., 1982).

The molecular weight of the CP was estimated by sodium dodecyl sulfate - polyacrylamide gel electrophoresis (SDS-PAGE) on a $3.5 \%$ stacking gel and a $12 \%$ resolving gel. A mixture of an equal amount of virus preparation and dissociation buffer $(0.125 \mathrm{M}$ Tris- $\mathrm{HCl}, \mathrm{pH} 6.7,3 \%$ SDS, $20 \%$ glycerol and $10 \%$ 2-mercaptoethanol) was boiled for 5 min. After electrophoresis for $2 \mathrm{~h}$ at $120 \mathrm{~V}$ at room temperature, proteins were stained with coomassie brilliant blue. Protein molecular weight was estimated by comparing their relative mobility with molecular weight standards (Low molecular weight calibration kit-Amersham Biosciences , NJ, USA).

For western blot analysis, the protein was blotted onto nitrocelulose membrane (Sigma N-8142) and transferred by a Hoefer MiniVE device (Amersham Pharmacia, NJ, USA) at $300 \mathrm{~mA}$ for $90 \mathrm{~min}$. Immunostaining was carried out according to Lenardon et al. (1993). A TSV antiserum was provided by W. J. Kaiser, Washington State University, Pullman, WA, USA. For virus detection alkaline phosphatase conjugated with goat-antirabitt antibodies (A 8025; Sigma, USA) diluted to 1:5,000 and substrate BCIP/NBT (Sigma B-1911) was used.

\section{Antisera production and serological determinations}

Two New Zealand rabbits were immunized with intramuscular injections of $100 \mu \mathrm{g}$ of purified virus, which had been suspended in saline $(0.15 \mathrm{M} \mathrm{NaCl})$ and emulsified in an equal volume of Freund's complete adjuvant. Second, third and fourth injections were prepared with incomplete adjuvant, containing the same amount of virus at ten-day intervals. Bleedings began four weeks after the first injection and continued for six weeks. Antisera were stored at $-5^{\circ} \mathrm{C}$.

\section{Enzyme-linked immunosorbent assay analysis}

Immunoglobulin was prepared according to Clark \& Bar-Joseph (1984) using ammonium sulphate precipitation. Virus diagnosis was done by indirect ELISA (Koenig, 1981). The uppermost fully developed soybean leaves were ground in ELISA extraction buffer (4 $\mathrm{ml}$ of 
buffer/g leaf). Microtiter plates were covered with antigen previously prepared in coating buffer at 1:200 dilution and incubated for $2 \mathrm{~h}$ at $37^{\circ} \mathrm{C}$. Immunoglobulin was used at $0.8 \mu \mathrm{g} / \mathrm{ml}$. Goat anti-rabbit IgG alkaline phosphatase conjugate (A-8025, Sigma Immuno-Chemicals, USA) was used at 1:8,000 dilution and incubated for $2 \mathrm{~h}$ at $37{ }^{\circ} \mathrm{C}$. Twenty minutes after adding the substrate (p-nitrophenil phosphate) absorbance $\left(\mathrm{A}_{405 \mathrm{~nm}}\right)$ was read on a ELISA reader (Microplate Reader, Mod. 3550 UV, BioRad, USA). A reaction was considered positive if the reading exceeded two times the mean value for healthy tissue.

\section{Electron microscopy}

Viral particles were also observed in purified preparations negatively stained with uranyl acetate (Kitajima \& Nome, 1999).

\section{RNAs extraction and reverse transcription.}

Infected young tobacco 'Sansun' leaves were frozen with liquid nitrogen and pulverized in a mortar. Nucleic acid preparations enriched in dsRNAs were obtained by extraction with buffer-saturated phenol and fractionated by column chromatography on non-ionic cellulose (CF-11, Whatman) as described by Dodds \& Bar-Joseph (1983). Reverse transcription was done using CF11-prepared RNA as a template. Ten $\mu 1$ RNA samples were taken and mixed with $2 \mu \mathrm{l}(10 \mu \mathrm{M})$ of primer 3TbS3 (5'-GCATCTCCTATAA AGGAGGC-3'), incubated at $80^{\circ} \mathrm{C}$ for $3 \mathrm{~min}$ and quenched on ice. In sequence, other reaction components were added in the following order: $6 \mu \mathrm{l}$ of $5 \mathrm{X}$ RT first strand buffer (200 mM Tris-HCl, pH 8.4), $1 \mu \mathrm{l}$ of dNTP mix (10 mM), 2 $\mu \mathrm{l}$ of DTT $(0.1 \mathrm{M}), 2 \mu \mathrm{M}$ M-MLV reverse transcriptase (20 $\mathrm{U})$ (Gibco BRL), and DEPC treated water to give a reaction volume of $30 \mu \mathrm{l}$. The tubes were incubated for $1 \mathrm{~h}$ at $37{ }^{\circ} \mathrm{C}$ on a thermocycler MJ model PTC 200 (MJ Research Inc., Waltham, MA, USA) followed by $5 \mathrm{~min}$ of heating at $99^{\circ} \mathrm{C}$ to denature the enzyme.

\section{Amplification of coat protein gene by PCR}

The PCR reactions were performed in $50 \mu \mathrm{l}$ volume containing $5 \mu \mathrm{l}$ of PCR buffer (10X), $5 \mu \mathrm{l}$ of $\mathrm{MgCl}_{2}, 10 \mu \mathrm{l}$ of dNTP mix $(10 \mathrm{mM}), 1 \mu \mathrm{l}$ Taq DNA polimerase $(5 \mathrm{U} / \mu \mathrm{l})$, $5 \mu \mathrm{l}$ reverse transcribed sample, $20 \mu \mathrm{LEPC}$ water and $2 \mu \mathrm{l}$ of each primer $(10 \mu \mathrm{M}) 3 \mathrm{TbS} 3$ and TbCP5U (5'-GCTTCTC GGACTTACCTGAG-3'). The reaction mixture was heated at $94^{\circ} \mathrm{C}$ for $3 \mathrm{~min}$ followed by 35 cycles at $94^{\circ} \mathrm{C}$ for $30 \mathrm{sec}$, $55^{\circ} \mathrm{C}$ for $1 \mathrm{~min}$ and $72^{\circ} \mathrm{C}$ for $2 \mathrm{~min}$ followed by $10 \mathrm{~min}$ incubation at $72^{\circ} \mathrm{C}$. The PCR amplified fragment was cloned into a plasmid vector, pBluescript II KS+ (STRATAGENE) according to the manufacturer's protocol.

\section{Nucleotide sequencing, sequence comparison and phylogenetic analysis}

Nucleotide sequences from three clones were performed by comparison with those available in GenBank and EMBL databases. Multiple sequence alignments and dendrograms of sequence relationship were produced using CLUSTAL W (Thompson et al., 1994). The translation product was estimated through the translate routine from Expasy software (http://us.expasy.org/tools/). The open reading frame was evaluated through the http:// www.ncbi.nih.gov/gorf/gorf.html. The calculation of identity and similarity was performed by analysis on http:// bioinformatics.org/sms/ident_sim.html. The phylogenetic relationships were established by maximum parsimony, with software PAUP v.4.0b10. The reliability of the tree was examined by a bootstrap test with 1000 replicates.

\section{RESULTS}

\section{Virus isolate and host range}

After mechanical inoculation several plant species from seven families were infected by the TSV isolate used in this study (Table 1). The TSV infected 18 out of 26 plant species. Soybean plants reacted with the same symptoms observed in the field, exhibiting bud blight seven to ten days after inoculation. No symptoms were observed in Amaranthus sp., abobrinha (Cucurbita pepo L.), Pisum sativum L., Crotalaria pallida Ait, and C. spectabilis Roth. These inoculated plants were indexed by mechanical inoculation in $N$. tabacum cv. Samsun and no symptoms were observed.

\section{Virus purification and nucleoprotein analysis}

The purification method yielded 1.4-2.6 mg virus/ 100 $\mathrm{g}$ of leaves. The 260/280 ratios ranged from 1.43 to 1.56 , typical of spherical viruses. Viral preparation showed a specific profile after sucrose gradients typical of ilarviruses with three peaks corresponding to top, medium and bottom components.

The CP migrated in SDS-PAGE as a single band with a molecular mass of $29.880 \mathrm{kDa}$ (Figure 1A). Western blots that were probed with TSV polyclonal using antiserum prepared by W. J. Kaiser (Washington State University, USA) showed a single band in the same position at the SDS-PAGE (Figure 1B).

\section{Antisera production and serological determinations}

Antibodies raised to TSV on rabbits reacted lightly with healthy soybean sap and were used in indirect ELISA only after cross absorption with healthy plant sap (Figure 2). Cross absorbed IgG decreased the absorbance values without significantly affecting the detection of TSV.

\section{Electron microscopy}

Electron microscope analysis of infected leaves showed spherical virus particles measuring $28 \mathrm{~nm}$ diameter (Figure 3).

Nucleotide sequencing, sequence comparison and phylogenetic analysis

The PCR tests using specific primers for the TSV 
TABLE 1 - Symptoms induced in plants by Tobacco streak virusBrazilian strain, isolated from soybean (Glycine max)

\begin{tabular}{|c|c|c|}
\hline $\begin{array}{l}\text { Botanical } \\
\text { family }\end{array}$ & Species & Reaction' \\
\hline \multirow[t]{2}{*}{ Amaranthaceae } & Gomphrena glohasa L. & CLL \\
\hline & Amaranthus sp. & - \\
\hline \multirow[t]{2}{*}{ Asteraceae } & Emilia sonchifolia (L.) DC & M \\
\hline & Bidens pilasa $\mathrm{L}$. & M \\
\hline \multirow[t]{2}{*}{ Chenopodiaceae } & Chenopodium amaranticolor Coste \& Reyn. & NLL \\
\hline & C. quinoa Willd. & CLL \\
\hline Cucurbitaceae & Cucurbita pepo L. 'Caserta' & - \\
\hline \multirow[t]{13}{*}{ Fabaceae } & Glycine max L. Mer. & \\
\hline & c.v. Santa Rosa & $\mathrm{SN}$ \\
\hline & c.v. Davis & $\mathrm{SN}$ \\
\hline & Phaseolus vulgaris L. & \\
\hline & c.v. Rosinha & NLL \\
\hline & c.v. Carioca & NLL \\
\hline & c.v. Tibagi & CLL \\
\hline & Lupinus albus L. & $\mathrm{M}$ \\
\hline & Crotalaria pallida Ait & - \\
\hline & C. spectabilis Roth. & - \\
\hline & Arachis hypogeae L. & M \\
\hline & Vigna unguiculata (Walplalp. Piti ba & - \\
\hline & Pisum sativum $\mathrm{L}$. & - \\
\hline Gramineae & Zea mays L. & - \\
\hline \multirow[t]{6}{*}{ Solanaceae } & Lycopersicom esculentum Mill. & M \\
\hline & N. tahacum L. Sansun NN & WCN \\
\hline & $N$. glutinasa L. & WCN \\
\hline & N. debneyi Domin. & $\mathrm{M}$ \\
\hline & N. benthamiana Domin. & $\mathrm{M}$ \\
\hline & Gossypium hirsutum L. & M \\
\hline
\end{tabular}

${ }^{1} \mathrm{WCN}=$ white circle necrosis; $\mathrm{M}=$ mosaic; $\mathrm{NLL}=$ necrotic local lesion; $\mathrm{CLL}=$ chlorotic local lesion;

isolate from white clover (Trifolium repens L.) (TSV WC) yielded a fragment of $1028 \mathrm{nt}$. The fragment included the gene of the 717 nucloetide $\mathrm{CP}(\mathrm{ORF})$ and a 287 nucleotide 3' untranslated region. The determined sequence was deposited at GenBank under the accession number AY354406.

The initiation codon for the CP ORF was at position 25 , and translation of this ORF resulted in a polypeptide of 238 amino acids which ends at a UAG termination codon at position 741 . The predicted molecular weight of the protein is $30,563 \mathrm{Da}$, slightly larger than the $29,880 \mathrm{Da}$ determined from the SDS-PAGE (Figure 1A). The deduced amino acid sequence shares $82.8 \%$ identity with TSV isolated from white clover (GenBank NC 3845) (Cornelissen et al., 1984) (Table 2).

Phylogenetic analysis was performed and the trees for nucleotides and amino acids showed similar results (Figure 4). The TSV-BR, TSV- WC (this is designated as TSV-NC in Figure 4 and needs to be changed there) and TSV- mungbean [Vigna radiata L. (Wilzed)] (AF515823) cluster in the same branch. The TSV-BR was more distantly related with SNSV and HdMV and had a limited homology with other ilarviruses compared.

Analysis of the $\mathrm{CP}$ amino acid sequence exhibited the cysteine motif $\mathrm{C}-\mathrm{X}_{2}-\mathrm{C}-\mathrm{X}_{10}-\mathrm{C}-\mathrm{X}_{2}-\mathrm{H}$ in the amino acid positions 26 to the 44 which can form a possible "zinc finger" type-binding domain (Figure 5).

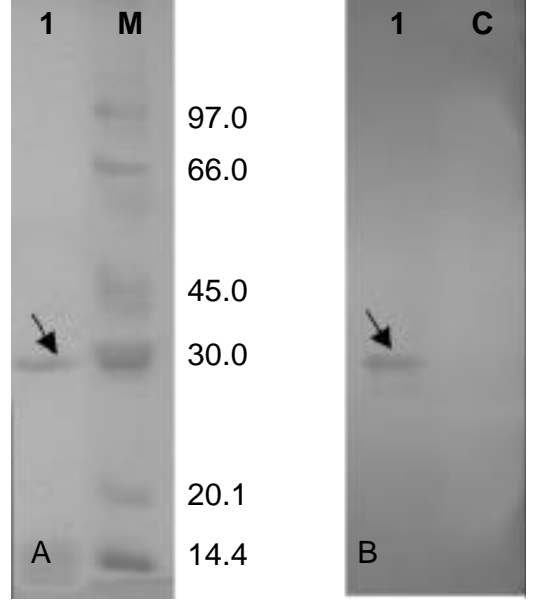

FIG. 1 - (A) SDS-PAGE of proteins from dissociated Tobacco streak virus (TSV) on $12.5 \%$ polyacrilamide gel. Lane 1, TSV-BR ( 29,8kDa). Lane M, molecular weight markers (LMW Marker Kit; Amersham Biosciences). $\mathrm{B}=$ western blot from the gel (A) of infected (1) and healthy extract (C).

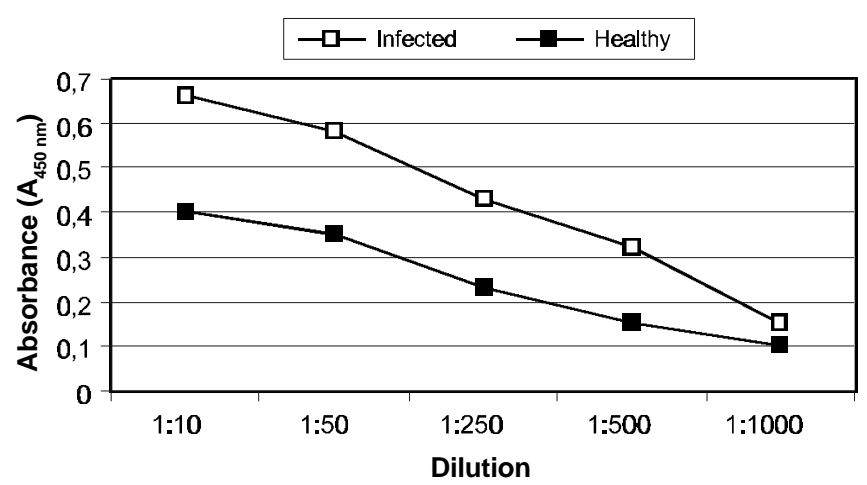

FIG. 2 - Indirect ELISA reaction against a polyclonal Tobacco streak virus (TSV) antiserum with infected and healthy samples of soybean (Glycine max) leaves, absorbed with healthy tissue.

The 287 nucleotide 3' untranslated region (UTR) of TSV-BR RNA 3 shows a high degree of similarity with TSV-WC (85\%) and SNSV (70.3\%) (data not shown). It contains a potential stem-loop structure with interpersed AUGC motifs, characteristic for ilarvirus and alfamovirus (Figure 6).

\section{DISCUSSION}

The virus analyzed in these studies shows the biological and molecular properties similar to those described for TSV (Fulton, 1971). Therefore, the outbreak of soybean bud blight that occurred in Wenceslau Braz County was definitely caused by an isolate of TSV.

The host range data is in agreement with several reports for TSV (Costa \& Carvalho, 1961; Salazar et al., 1982; Kaiser et al., 1982), despite the lack of infection of 


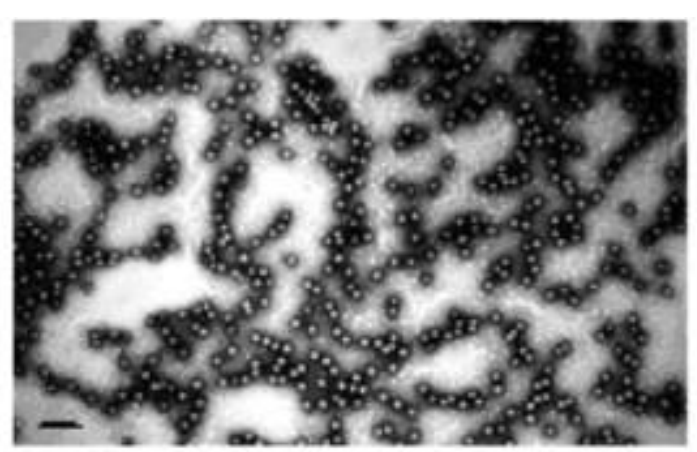

FIG. 3 - Transmission electron micrograph of purified virus particles of TSV-BR. Barr= $120 \mathrm{~nm}$.

Amaranthus sp., Crotalaria striata, C. mucronata, $C$. spectabilis, cowpea [Vigna unguiculata (L.) Walp.] and $P$. sativum previously mentioned as susceptible species by Costa \& Carvalho (1961).

Profiles from sedimentation of virus particles on sucrose frozen gradients were typical of ilarvirus, particularly TSV (Lister \& Bancroft, 1970). Virus purifications were always done using infected leaves from tobacco cv. Sansun 'NN'. However, the yield of virus as well as the proportion of each component varied among purifications throughout the year. Lister \& Bancroft (1970) also reported that alterations in TSV component ratios and yield were influenced by hosts and extraction procedure. In our case, only one species of tobacco and one method were used, and therefore, it is believed that other factors such as the effect of environmental conditions on plants could be responsible for the differences. For example, temperatures in the greenhouse ranged from $16^{\circ} \mathrm{C}$ in the winter up to 38 ${ }^{\circ} \mathrm{C}$ in the summer.

The CP from purified virus had a relative molecular mass close to those reported for ilarviruses (http:// image.fs.uidaho.edu/vide/descr811.htm). Amino acid analysis of the protein showed a molecular mass of 30,563 $\mathrm{Da}$, close to the values obtained from electrophoresis analysis

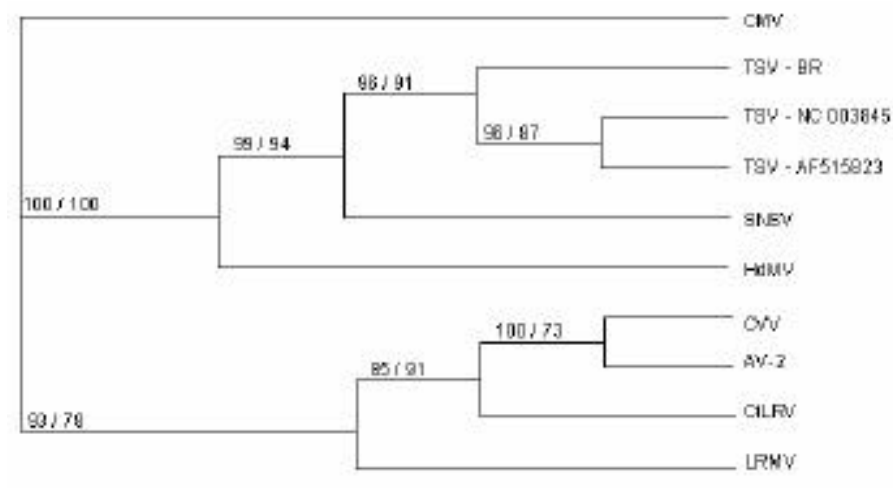

FIG. 4 - Phylogenetic analysis produced by Paup v.4.0b10 program, using the parsimony maximum method, indicating relationships among isolates of Tobacco streak virus (TSV) and others members of Ilarvirus genus. The analysis was made based on the complete sequence of coat protein. Numbers at each ramification indicated bootstrap percentages (based on 1,000 replications) for data from nucleotide and deduced amino acid analysis, respectively (nt/ aa). The sequences for comparison were obtained from GenBank with accession numbers for nucleotide and deduced amino acids respectively: TSV - white clover (Trifolium repens) (NC003845/ CAA25133) TSV- mungbean (Vigna radiata)(AF515823/ AAM76049), Strawberry necrotic shock virus - SNSV (AY363242/ AAQ76590). Hydrangea mosaic virus - HdMV (U35145/ AAA80345), Spinach latent virus - SpLV (NC003810/ NP620681), Citrus leaf rugose virus - CiLRV (NC3546/ NP613280), Lilac ringspot mosaic virus - LRMV (U17391/AAA64840), Citrus variegation virus - CVV (AF434918/ AAL37957), Asparagus virus 2 - AV-2 (X86352/ S54138).

(29,880 Da). In addition, particle measurements estimated by electron microscopy showed average sizes $(28 \mathrm{~nm})$ similar to those described for TSV.

The nucleotide sequence of the RNA3 from clones TSV-BR28, TSV-BR29 and TSV-BR39 permitted identification of a $1028 \mathrm{nt}$ sequence that revealed one open reading frame flanked by a 25 nucleotide portion of the intercistronic region and a 287 nucleotide 3 '-NTR. The folded tRNA-like motif of the 3'NTR observed in this isolate

TABLE 2 - Comparison on the percentage of identity among nucleotide sequences (below diagonal) and deduced amino acids (above diagonal) of the CP gene of Tobacco streak virus (TSV) and species of Ilarvirus genus deposited at GenBank: TSV(1) (Brazilian isolate, AY354406), TSV $^{(2)}$ [TSV-isolado de mungbean (Vigna radiata)(AF515823)], TSV ${ }^{(3)}$ (NC003845), Strawberry necrotic shock virus (SNSV) (AY363242), Hydrangea mosaic virus (HdMV) (U35145), Citrus variegation virus (CVV) (AF434918), Asparagus virus-2 (AV-2) (X86352), Lilac ring mottle virus (LRMV) (U17392), Citrus leaf rugose virus (CiLRV) (NC003546)

\begin{tabular}{|c|c|c|c|c|c|c|c|c|c|}
\hline $\mathrm{Nt} / \mathbf{n a}$ & TSV $^{1}$ & $\mathrm{TSV}^{2}$ & $\mathrm{TSV}^{3}$ & SNSV & HdMV & CVV & AV-2 & LRMV & CiLRV \\
\hline TSV $^{1}$ & & 80.8 & 82.8 & 62.3 & 46.9 & 18.4 & 18.4 & 15.7 & 17.3 \\
\hline TSV $^{2}$ & 80.7 & & 89.8 & 63.3 & 47.3 & 18.4 & 18.8 & 17.3 & 17.7 \\
\hline TSV $^{3}$ & 81.3 & 88.9 & & 61.9 & 46.7 & 17.6 & 18.4 & 16.1 & 17.0 \\
\hline SNSV & 63.9 & 65.7 & 64.8 & & 44.7 & 22.7 & 22.3 & 17.4 & 19.1 \\
\hline HdMV & 56.8 & 58.6 & 58.1 & 53.8 & & 20.5 & 20.5 & 16.3 & 18.1 \\
\hline CVV & 41.0 & 41.0 & 40.7 & 40.1 & 40.1 & & 75.1 & 34.1 & 63.5 \\
\hline $\mathbf{A V}-\mathbf{2}$ & 39.7 & 40.3 & 39.9 & 40.9 & 40.0 & 76.3 & & 34.1 & 59.5 \\
\hline LRMV & 31.2 & 31.8 & 32.2 & 31.1 & 30.5 & 48.0 & 49.7 & & 36.1 \\
\hline CiLRV & 37.6 & 37.7 & 38.1 & 37.4 & 38.3 & 65.1 & 62.0 & 47.6 & \\
\hline
\end{tabular}




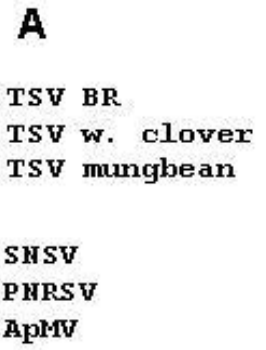

MKTLNQGPDHPSNUMA SRANNR--NGSRCPTCFD-ELDALARNC SLHPPA MNTLIQGPDHPSNAMS SRANNR SNN- SRCPTCID-ELDAMARNCPAHNTV MNTLIQGPDHP SNAMS SRTNNRF NNNSR CPTCFD-ELDAVARGC $P A H_{A P A}$

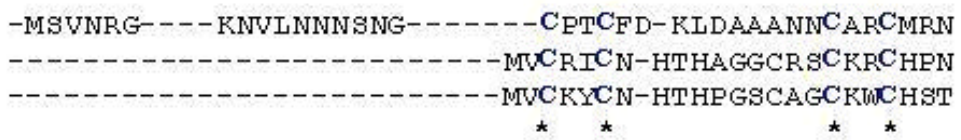

FIG. 5 - A: Alignment of amino acid sequences of the CP N-terminal region of several Tobacco streak virus (TSV) isolates and other ilarviruses. The positions of the conserved cysteine amino acids in the CP are marked with asterisks. B: Putative "zinc finger" motif present at the amino-terminus of the TSV-BR CP. The sequences for comparison were obtaneid from GenBank with accession numbers for deduced amino acids: TSV white clover (Trifolium repens) (CAA25133); TSV mungbean (Vigna radiata) (AAM76049); TSV cotton (Gossypium hirsutum) (AAM76050); TSV sunn-hemp (Crotalaria juncea) (AAM76051); TSV sunflower (Helianthus annuus) (AAL31701); SNSV (AAQ76588); Prunus necrotic shock virus (PNRSV) (NP733825); Apple mosaic virus (ApMV) (NP604485).
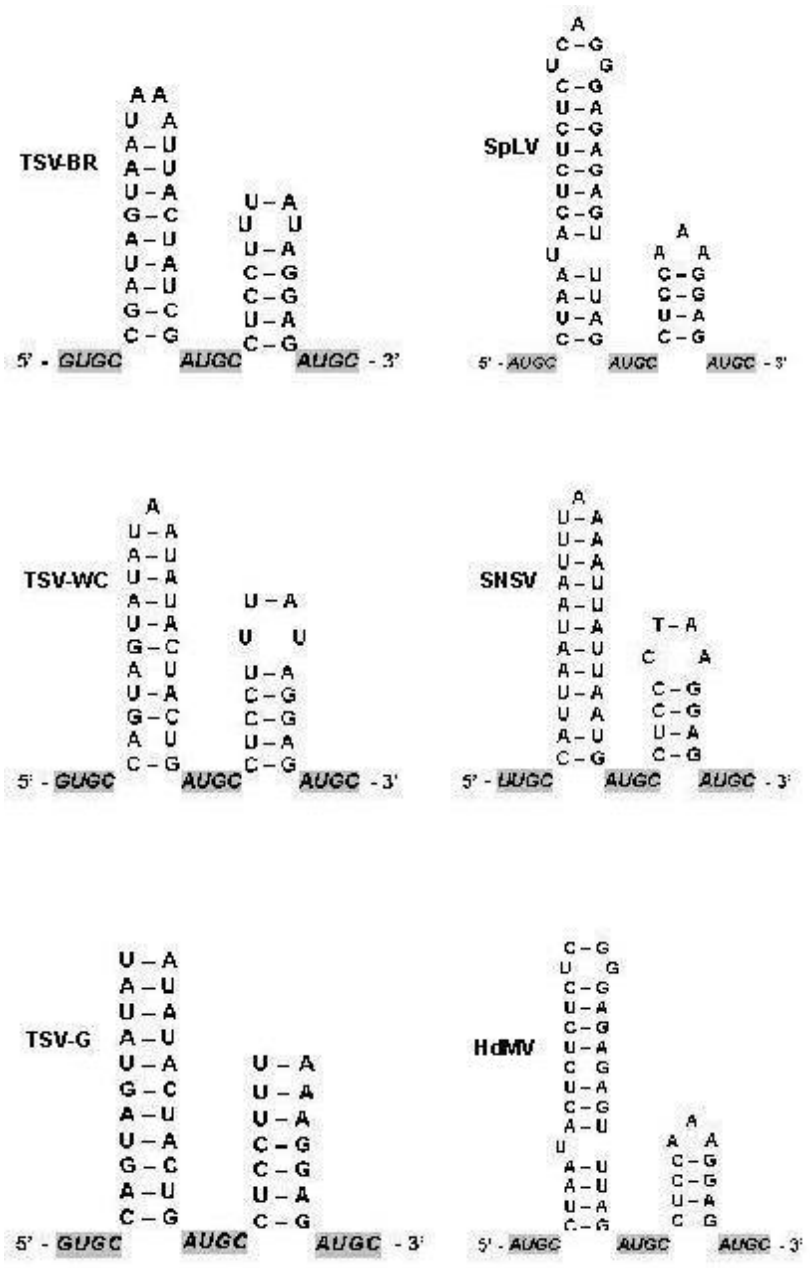

FIG. 6 - Possible secondary structures at the 3'-temini of Tobacco streak virus brazilian isolate (TSV- BR) and other ilarviruses. The conserved AUGC sequences are boxed and shaded. Structures were designed based on sequence data from GenBank: TSV - white clover (Trifolium repens) (NC003845), TSV - G [groundnut (Arachis hypogaea), Cook et al., 1999], Spinach latent virus (SpLV) (NC003810), Citrus leaf rugose virus (CiLRV) (NC3546), Hydrangea mosaic virus - HdMV (U35145/), Strawberry necrotic shock virus (SNSV) (AY363242). is predicted to have an important role in the virus infection by binding the $\mathrm{CP}$ as it does for other ilarviruses and alfamoviruses (Vloten-Doting, 1975; Bol, 1999). The ORF codes for a Mr 29,880 product that corresponds to the viral CP. This value is larger than the $\mathrm{Mr} 26,346$ described by Cornelissen et al. (1984) for the CP of an isolate of TSV obtained from white clover but is close to the value mentioned by Salazar et al. (1982). The CP of this strain shares an $82 \%$ amino acid sequence identity with that of the TSV strain WC.

Parsimony phylogenetic analyses for nucleotide sequences were obtained. The nucleotide sequence of this virus showed close association to TSV-WC (NC003845). Based on the proposal of Regenmortel et al. (1997) and Bhat et al. (2002) and assuming a threshold level of $90 \%$ similarity in the CP sequence, we consider the soybean virus to be a new strain of TSV isolated in Brazil.

A cysteine motif $\mathrm{C}-\mathrm{X}_{2}-\mathrm{C}-\mathrm{X}_{10}-\mathrm{C}-\mathrm{X}_{2}-\mathrm{H}$ that may form a "zinc finger" type-binding domain as described by Berg (1986) is found in the TSV-BR CP sequence can be between the $28^{\text {th }}$ and $46^{\text {th }}$ amino acids, as it is for all sequenced isolates (Sehnke et al., 1989). A similar structure also occurs in SNSV, APMV and PNRSV (Guo et al., 1995) but is located in the position of amino acids 2 to 13 and presents $\mathrm{C}-\mathrm{X}_{2}-\mathrm{C}$ $\mathrm{X}_{10}-\mathrm{C}-\mathrm{X}_{2}-\mathrm{C}$ pattern.

The N-terminal region of the $\mathrm{CP}$ is highly conserved in sequenced TSV isolates and has been shown to be necessary for binding the CP to the 3 ' end of ilarvirus and AMV RNAs (Baer et al., 1994). This indicates the possibility of involving a process of genome activation and/or interaction of the protein with genomic RNAs for virion formation.

The folded stem-loop structure of the 3'NTR is flanked by tetranucleotide AUGC motifs in this isolate as well as in other ilarviruses and AMV, and this motif has an important role in the virus infection by binding to $\mathrm{CP}$ (Vloten-Doting, 1975; Bol, 1999). Although several AUGC motifs are conserved among ilarviruses and AMV RNAs, 
TSV isolates have two AUGC motifs as well as third GUGC motif in a proximal position in the 3 ' terminal region.

Nucleotide and amino acid sequences of TSV-BR present serological, ultrastructural and biological characteristics that demonstrate structural and molecular similarities of TSV-BR with other TSV isolates, indicating a close relationship between them. This is the first report of the biological and molecular characterization of TSV from soybean, and we believe that the PCR primers designed for use in this work will be helpful as a primary diagnostic tool for TSV-BR.

\section{ACKNOWLEDGMENTS}

We thank Dr. Taurino A. Loiola for reporting the outbreak of soybean bud blight and helping in collecting infected plants. We are also grateful to The National Council for Scientific and Technological Development (CNPq) and the Japanese International Research Center for Agricultural Science (JIRCAS) for financial support provided to A.M.R.A. for the execution of this work. We thank L. C. Benato and N. Valentin for technical assistance in this project and Dr. J. F. Ferraz de Toledo for reviewing the manuscript.

Approved by the Head of Research and Development of Embrapa Soybean as manuscript 13/2004.

\section{LITERATURE CITED}

ALMEIDA, A. M.R. \& CORSO, I. C. Effect of sowing time on the incidence of bud blight in soybean (Glycine max L. Merr.). Journal of Phytopathology 132:251-257. 1991.

ALMEIDA, A.M.R., BERGAMIN FILHO, A. \& AMORIM, L. Disease progress of soybean bud blight and spatial pattern of diseased plants. Journal of Plant Disease and Protection 101:386392. 1994.

BAER, M., HOUSER, F., LOESCH-FIRES, S.L. \& GEHRKE, L. Specific RNA binding by amino-terminal peptides of alfalfa mosaic virus coat protein. EMBO Journal 13:727-735. 1994.

BHAT, A.I., JAIN, R.K., KUMAR, A., RAMIAH, M. \& VARMA, A. Serological and coat protein sequence studies suggest that necrosis diseases on sunflower in India is caused by a strain of Tobacco streak virus. Archives of Virology 147:651-658. 2002.

BAXTER-GABBARD, K.L. A simple method for the large scale preparation of sucrose gradients. FEBS Letters 20:117-119. 1972.

BOL, J.F. Alfalfa mosaic virus and ilarviruses: involvement of coat protein in multiple steps of the replication cycle. Journal of General Virology 80:1089-1102. 1999.

BERG, J.M. Potential metal binding domains in nucleic acid binding proteins. Science 23:485-486. 1986.

CLARK, M.F. \& BAR-JOSEPH, M. Enzyme immunosorbent assay in plant virology. In. Maramorosh, K. \& Koprowski, H. (Eds.) Methods in virology. New York, Academic Press. 1984. pp.51-85.

COOK, G., MIRANDA, H.R., ROOSSINCK, M.J. \& PIETERSEN, G. Tobacco streak ilarvirus detected on groundnut in South Africa. African Plant Protection 5:13-19. 1999.
CORNELISSEN, B.J.C., JANSSEN, H., ZUIDERMA, D. \& BOL, J.F. Complete nucleotide sequence of Tobacco streak virus RNA 3. Nucleic Acids Research 12:2427-2437. 1984.

COSTA, A.S. The relationship between American tobacco streak and Brazilian "necrose branca" or "couve". Phytopathology 35:10291030. 1945.

COSTA, A.S. Queima do broto, sintoma induzido em soja por vários vírus. Summa Phytopathologica 8:18-19. 1982.

COSTA, A.S., LIMA, A.R. \& FORSTER, R. Necrose branca, uma moléstia de vírus do fumo (Nicotiana tabacum L.) e fumo couve como sintoma tardio. Journal de Agronomia 3:1-26. 1940.

COSTA, A.S., MIYASAKA, S. \& D’ANDREA PINTO, A. J. Queima dos brotos da soja, uma moléstia causada pelo vírus da necrose branca do fumo ou couve. Bragantia 14:VII-X. 1955.

COSTA, A. S. \& LIMA NETO, V. C. Transmissão do vírus da necrose branca do fumo por Frankliniella sp. In: Resumos, IX Congresso Brasileiro de Fitopatologia. Campinas, SP. 1976.

COSTA, A.S. \& CARVALHO, A.M.B. Studies on Brazilian tobacco streak. Phytopathologische Zeitschrift 42:113-138. 1961.

DAVIS, P.B. \& PEARSON, C.K. Characterization of density gradients prepared by freezing and thawing a sucrose solution. Analytical Biochemistry 91:343-349. 1978.

DODDS, J.A. \& BAR-JOSEPH, M. Double straded RNA from plants infected with closteroviruses. Phytopathology 73:419-423. 1983.

FULTON, R. W. Tobacco streak virus. Descriptions of plant viruses. No. 44. Commonwealth Mycology Institute. N.44. 1971.

GUO, D., MAISS, E., ADAM, G. \& CASPER, R. Prunus necrotic ringspot ilarvirus:nucleotide sequence of RNA 3 and the relationship to other ilarviruses based on coat protein comparison. Journal of General Virology 76:1073-1079. 1995.

GREBER, R S., KLOSE, M.J. \& TEAKLE, D.S. High incidence of tobacco streak virus in tobacco and its transmission by Microcephalothrips abdominalis and pollen from Ageratum houstonianum. Plant Disease 75:450-452. 1991.

KAISER, W. J., WYATT, S. D. \& PESHO, G. R. Natural hosts and vectors of tobacco streak virus in Eastern Washington. Phytopathology 72:1508-1512. 1982.

KITAJIMA, E.W. \& NOME, C.F. Microscopia electrónica em virologia vegetal. In: Docampo, D.M. \& Lenardón, S.L. (Eds.) Métodos para detectar patógenos sistémicos. Córdoba, IFFIVE/ INTA-JICA. 1999. pp. 59-87.

KOENIG, R. Indirect ELISA methods for the broad specificity detection of plant viruses. Journal of General Virology 55:53-62. 1981.

LENARDON, S.L., GORDON, D.T. \& GINGERY, R.E. Serological differentiation of Mayze dwarf mosaic potyvirus strains A, D, E, and F by electro-blot immunoassay. Phytopathology 83:86-91. 1993. LISTER, R.M. \& BANCROFT, J.B. Alteration of tobacco streak virus component ratio is altered by host and extraction procedure. Phytopathology 60:689-694. 1970.

REGENMORTEL, M.H.V., FAUQUET, C.M., BISHOP, D.H.L., MAYO, M.A., MANILOFF, J. \& CALISHER, C.H. Guidelines to the demarcation of virus species. Archives of Virology 147:651658. 1997.

SALAZAR, L.F., ABAD, J.A. \& HOOKER, W.J. Host range and 
properties of a strain of tobacco streak virus from potatoes. Phytopathology 72:1550-1554. 1982.

SEHNKE, P.C., MASON, A.M., HOOD, S.J., LISTER, R.M. \& JOHNSON, J.E. A "zinc-finger"- type binding domains in tobacco streak virus coat protein. Virology 168:48-56. 1989.

THOMPSON, J.D., HIGGINS, D.G. \& GIBSON, T.J. Clustal $\mathrm{W}$ :Improving the sensitivity of progressive multiple sequence alignment through sequence weighting, position. specific gap penalties and weight matrix choice. Nucleic Acids Research 22:4673-4680. 1994.

VLOTEN-DOTING, L.VAN. Coat protein is required for infectivity of tobacco streak virus:biological equivalence of the coat proteins of tobacco streak and alfalfa mosaic viruses. Virology 65:215-225. 1975. 